INSIGHTS INTO REGIONAL DEVELOPMENT

ISSN 2669-0195 (online) http://jssidoi.org/IRD/

2019 Volume 1 Number 4 (December)

http://doi.org/10.9770/IRD.2019.1.4(6)

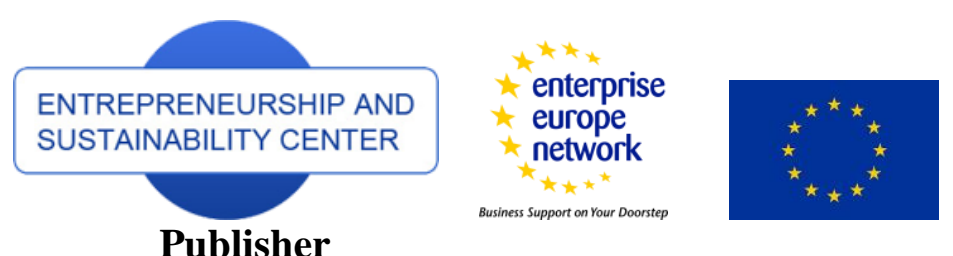

http://jssidoi.org/esc/home

FORESIGHT FOR SUSTAINABLE ENERGY POLICY IN EGYPT: RESULTS FROM A DELPHI SURVEY*

\author{
Mohamed Ramadan A. Rezk ${ }^{1}$, Amr Radwan'², Nahed M. Salem³, Mahmoud M. Sakr ${ }^{4}$, \\ Manuela Tvaronavičiené ${ }^{5}$ \\ 1,2,3,4Academy of Scientific Research and Technology (ASRT),101 Elkasr Alini St,11516, Cairo, Egypt \\ ${ }^{5}$ Vilnius Gediminas Technical University, Sauletekio 11, 10223 Vilnius, Lituania \\ E-mails: ${ }^{1}$ mramadan79@gmail.com,${ }^{2 *} \frac{\text { radwan.amro@gmail.com }}{5}$ (corresponding author), ${ }^{3}$ nahedelashkar.asrt@gmail.com, \\ ${ }^{4}$ msakr@asrt.sci.eg, ${ }^{5}$ manuela.tvaronaviciene@vgtu.lt
}

Received 18 May 2019; accepted 10 September 2019; published 15 December 2019

\begin{abstract}
This paper presents energy opportunities, particular areas of high potential and reflections on energy challenges in Egypt by the year 2040. Energy foresight significantly contributes in the effective review and formulation of national energy policies and strategies. In this work, 350 experts participated in real-time Delphi survey and responded to a set of structured and cross-linked questionnaires that aim to assess and provide future dimension to the energy sector in Egypt. Priorities are presented across 14 energy cluster-areas with 180 identified topics. The two-round Delphi study with an iterative process was performed to determine and measure the expectations of the different stakeholders with specific emphasis on the prospects of renewable energy and energy efficiency. The designed cross-linkages between survey components allowed the systematic pooling and convergence of knowledge in addition to the technical insights and different perspectives. About 50\% of Egypt's energy demand was foresighted to be met by renewable energies around 2030. The results showed that all types of energy would not only provide economic and environmental benefits but also improve living standards. This work demonstrates that involving large diversity of expertise and different stakeholders, comprising heterogeneous groups, in foresight studies would potentiate the forecasting power, reduce the polarization effect, and enhance the reliability of the foresight exercise.
\end{abstract}

\footnotetext{
* This research was supported by the project, which has received funding from the European Union's Horizon 2020 research and innovation programme European Research Council (ERC) under the European Union's Horizon 2020 research and innovation programme Marie Sklodowska-Curie Research and Innovation Staff Exchanges ES H2020-MSCA-RISE-2014 CLUSDEVMED (2015-2019) Grant Agreement Number 645730730
}
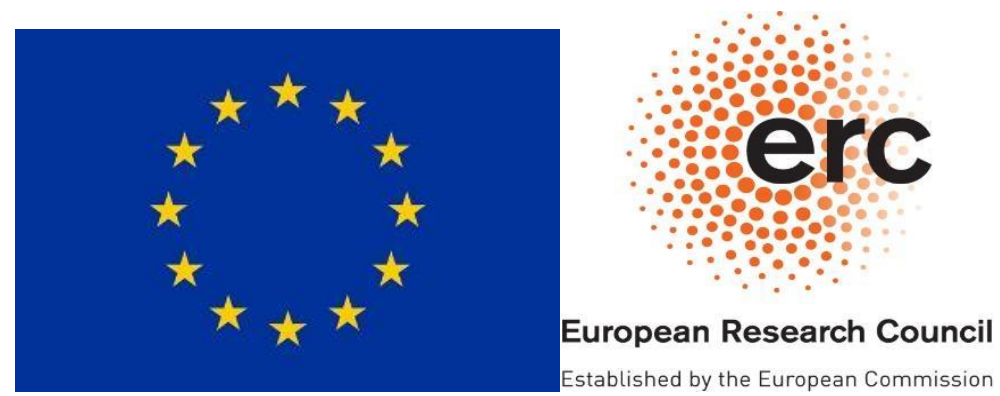


\section{INSIGHTS INTO REGIONAL DEVELOPMENT}

ISSN 2669-0195 (online) http://jssidoi.org/jesi/

2019 Volume 1 Number 4 (December)

http://doi.org/10.9770/IRD.2019.1.4(6)

Keywords: science policy; foresight; Delphi survey; energy; sustainable development; renewable energy

Reference to this paper should be made as follows: A. Rezk, M.R., Radwan, A., Salem, N.M., Sakr, T.M., Tvaronavičienė, M. 2019. Foresight for sustainable energy policy in Egypt: results from a Delphi survey. Insights into Regional Development, 1(4), 357-369. https://doi.org/10.9770/ird.2019.1.4(6)

JEL Classifications: 021, 032, 038

Additional disciplines political sciences; ecology and environment; environmental engineering

\section{Introduction}

At the national level, the energy policies enact in the near future in Egypt could have a significant effect on both the energy efficiency and renewable energy. Many authors consider these two folds as the twin pillars of the sustainable energy policy (Armin Razmjoo, Sumper et al. 2019). The formulation of sustainable energy policies influences the economic development, environmental resource management and social acceptance. Many policies and strategic visions of developing countries set a long-term target for the national contribution of renewable energy and the overall energy efficiency. Despite these targets are usually perceived as highly ambitious, it requires augmentation of several policy tools to effectively anticipate challenges and opportunities (Radwan and Sakr 2017, Radwan 2018).

In this respect, it is important to understand how Egypt's energy matrix has evolved and it is even more important to consider this pattern of evolvement in analyzing the possible forecasted scenarios for future energy policies and national interventions (Rezk et al. 2016; Armin Razmjoo, Sumper et al. 2019). The forecasted scenarios would help better identifying opportunities while anticipating possible policy and strategic implications (Okoli and Pawlowski 2004).

While research on forecasting has mostly examined several technical aspects, technological-based forecasting research are less performed in many developing countries and hence, less contributing to national policy development (Okoli and Pawlowski 2004, Ghinolfi, El Baz et al. 2014). Energy future studies are usually implemented on the basis of foresight method with a combination of qualitative and quantitative tools, effective participation of experts and decision-makers. Many Studies have made important contributions to explore and define energy technology future (Lee and Yang 2018, Proskuryakova 2019). Technology foresight is a process comprising different techniques in developing mid-term future scenarios regarding the advancements in the use and production of technology and with the overall aim of identifying the areas of strategic importance and the emerging technologies are more likely to yield higher economic and social benefits (Rowe and Wright 2011). Delphi method, one of the important forecasting techniques, is commonly used in assessing specific aspects in the future and is frequently used in many energy foresight studies (Renzi and Freitas 2015). Being widely used in different research fields, the Delphi method is also known for harvesting the intelligence capacity of different expertise while making unified opinions to support the decision-making process.

Egypt has high potential of natural resources including natural gas, oil, coal and high reserves of fossil fuel energy sources; about 4189 billion barrels of oil reserve and about 77200 billion cubic meters of natural gas reserve (Table 1). The reserves are in the form of both mainland and coastal deposits (Ibrahim 2012, Shouman 2017). During the time of the late 1990s and mid-2000s, Egypt experienced helpful conditions regarding the findings of enormous natural gas holds in several locations, which contributed to different developmental plans and strengthened Egypt's position as natural gas producer and exporter (Suding 2011). This might be related to the increased consumption of natural gas by $7 \%$ per year during the first decade of 2000 s with noticeable decrease in production by around 3\% yearly during the period of 2009-2013. Consequently, the natural gas exporting capacity 


\section{INSIGHTS INTO REGIONAL DEVELOPMENT}

ISSN 2669-0195 (online) http://jssidoi.org/jesi/

2019 Volume 1 Number 4 (December)

http://doi.org/10.9770/IRD.2019.1.4(6)

was limited to only 5\% of its total production in 2013 and eventually driving the country to start signing importing agreements in the following years of 2014 and 2015. On the other front, phasing out energy subsidies is clearly listed among the top priorities for policy makers (Breisinger, Mukashov et al. 2019). Egypt is by far the largest consumer of oil and natural gas in Africa while representing $22 \%$ of petroleum and other liquids of the continent's total consumption and $37 \%$ of its dry natural gas consumption. In 2016, the Supreme Council of Energy adopted the Egyptian Energy Strategy until 2035 and selected four different scenarios to guide energy planning in Egypt for the coming years with a target of 37.2\% of renewable energy contribution in 2035 (NREA 2019), see Table 1. In this respect conducting a foresight studies are paramount for effective strategic planning. In this context, the Delphi method is mainly used when long-term issues (up to 30 years) have to be assessed. It is also useful for looking at emerging developments where external factors are likely to have a determining effect and when social aspects could influence economic or technical considerations. As it implies, it supports the identification of statements (topics) that are relevant for the future through channeling the tacit and complex knowledge to a single statement and makes it possible to judge (Di Zio, Castillo Rosas et al. 2017), see Table 1.

Table 1. Egypt's Production of Different Energy Sources during the 2000s.

\begin{tabular}{|c|c|c|c|c|c|c|c|}
\hline & 2005 & 2012 & 2013 & 2014 & 2015 & 2016 & 2017 \\
\hline Coal & 14 & 0 & 0 & 0 & 0 & 0 & 0 \\
\hline Crude Oil & 30111 & 32142 & 29537 & 32825 & 33210 & 30835 & 31885 \\
\hline Natural gas & 35901 & 54839 & 50143 & 39084 & 34763 & 34763 & 35362 \\
\hline $\begin{array}{c}\text { Electricity from Fossil } \\
\text { Fuels }\end{array}$ & 8211 & 12250 & 12250 & 13431 & 14355 & 14514 & 14679 \\
\hline Hydro Electricity & 1087 & 1112 & 1113 & 1188 & 1155 & 1171 & 1187 \\
\hline $\begin{array}{c}\text { Electricity from } \\
\text { Renewables }\end{array}$ & 47 & 139 & 139 & 145 & 137 & 150 & 165 \\
\hline Refinery/Oil Porducts & 28561 & 24754 & 21836 & 25348 & 25676 & 26357 & 270565 \\
\hline
\end{tabular}

Source: African Energy Commission (AFREC 2017)

\section{Methodology}

The used Delphi method in this study comprises development of quantitative with qualitative metrics and the systematic utilisation of the experts' opinions and the insights gathered althrough the process. The Delphi is a well-established methodology in futures studies with evidence going back nearly 60 years (Gupta and Clarke 1996). Group of specialized experts served in the inception phase for identifying large set of topics based on literature review, existing policy briefs, strategies and Egypt vision 2030. Topics were then grouped per cluster area (table 2) and substructured to matrix of technical questions to develop specific questionnaire relevant to each target group. The Delphi method comprises iterative rounds (two or more) of the same questionnaire to the same respondents. This process continues until the answers converge to a specific line of argument. In the second round, the respondents were allowed to change their answers based on the summarized findings of the previous round. Besides, this iterative and opinion convergence process served the validation of reliability and robustness by a sensitivity analysis.

\subsection{Setting the survey topics}

The database of the Academy of Scientific Research and Technology in Egypt was used to select 350 experts regarding each of the 14 energy clusters' technical areas whilst each group include 25 experts comprising different and relevant expertise and background. Pre-defined criteria were used to select experts including major 


\section{INSIGHTS INTO REGIONAL DEVELOPMENT}

ISSN 2669-0195 (online) http://jssidoi.org/jesi/

2019 Volume 1 Number 4 (December)

http://doi.org/10.9770/IRD.2019.1.4(6)

and minor fields of expertise while respecting the specific quota for the different stakeholders. In this context and based on the outputs of the 14 groups, a workshop was organised to scientifically discuss these topics while ensuring wide acceptance of all involved participants. Afterwards, the experts were asked to conduct macro contextual analysis using foresight cards regarding the social, technology, economic, environment and political (STEEP) influences (Markley 2011). STEEP cards method contributes to the better understanding of probabilities of occurrence and impact of influence in the future until 2040 by taking into account the specific topics that could lead to resolve an existing problem and achieve a desired progress (Kononiuk and Magruk 2015). The experts selected 180 topics regarding the 14 energy cluster areas including technological and non-technological topics, see Table 2.

Table 2. Energy cluster-areas

Bioenergy including biomass, waste, bioethanol, biodiesel and biogas.

Energy efficiency including energy conversion, energy efficiency, distribution networks and energy transportation.

Enabling environments including social environment, energy pricing, enabling legislation and energy culture.

Energy storage including batteries and storage of solar energy

Environment Impact including environmental concerns with respect to air and water pollution, damage to public health, wildlife and habitat loss, water use, land use and global warming.

Fossil Fuels including coal, oil and natural gas.

Hydrogen energy including production and installation.

Materials for energy including material use, composite, raw materials and manufacturing.

Mixed energy technologies including solar wind energy, solar- bio energy and bio-hydro energy.

Nuclear Energy including nuclear fusion and nuclear stations.

Renewable energy (1) including wind, geothermal energy, wave power and hydropower.

Renewable energy (2) including concentrated solar power, solar heating, photovoltaics, solar thermal energy, solar architecture, molten salt power plants.

Transportation including roads and smart transportation.

Urban planning and Buildings including housing, technology codes and laws.

\subsection{Real time Delphi survey}

Real time Delphi was used with an online version of the structured survey to support convergence of opinion in real time (Di Zio, Castillo Rosas et al. 2017). Real time Delphi is known also for its convenience when addressing large target groups with higher response rate than other similar tools (Aengenheyster, Cuhls et al. 2017).

The survey was designed to evaluate the selected topics regarding:

- Importance (importance at the national or international levels or both),

- Governmental interventions; actions that the government should address in each topic with respect to strategy formulation, human resource, capacity building, legal system reform (including intellectual property rights), public research institution reform, industry support, social acceptance, required investment).

- Forecasted time of technological impact realization which shows the required duration for either of the technology, process or solutions to be ready at technical level.

- Forecasted time of social impact which shows the required duration for the adapted technology, service or solution to be either used, promoted or accepted by local communities.

Furthermore, participants were also asked to rank and identify sectors of technological and strategic importance i.e a specific feasible technology in the near future could contribute to a multilevel impact at social, technological and economic levels. Moreover, while considering the sensitivity of the analysis, participants were asked to assess their level of expertise for each cluster area. Each participant received personal invitation with a link to an online Delphi survey. The designed cross-linkages between survey components supported gathering of technical insights and different prospects on real time. 


\section{Results and discussion}

At the first round of the survey, all the experts expressed their opinions and answered all the required questions. For the second round, a number of respondents decreased to 190 experts who expressed their opinions in the view of the findings of the first round. The average response rate was 74\%. Most of the participants are males (70\% of the total number of participants). For all cluster-areas the number of males' participants was higher than female except in urban planning and building cluster where the percentage of females reached $56 \%$. The results showed that $64 \%$ of participants showed a high level of expertise, while $18 \%, 13 \%$ and $4 \%$ showed a moderate degree of expertise, a low degree of expertise and no relevant expertise, respectively (Figure 1).

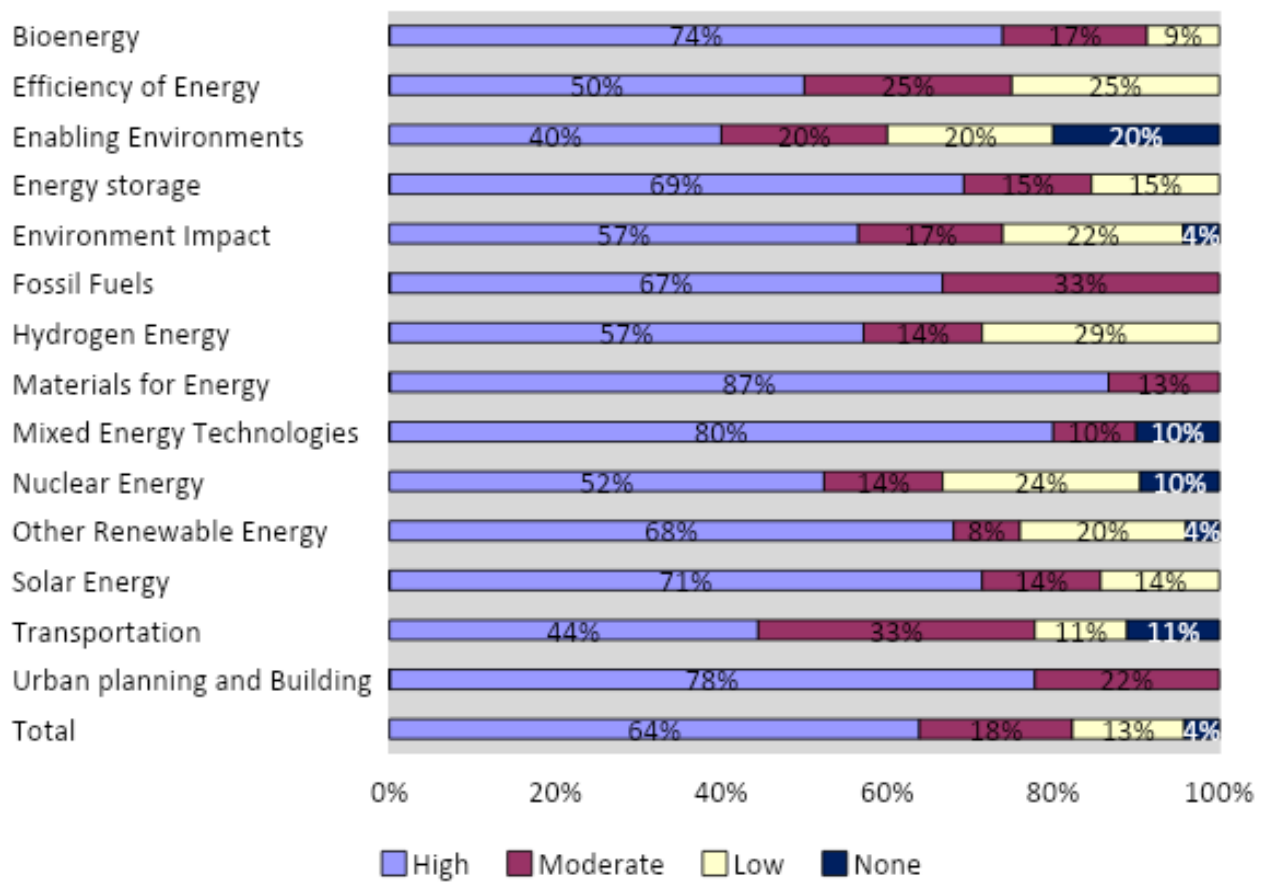

Figure 1. Distribution of Respondents by degree of expertise per cluster area

Since participants represent diverse groups of multidisciplinary backgrounds covering all aspects of energy from natural sciences and engineering to the social and human sciences, it is understandable to the authors to find different experience levels, to a specific cluster area, recorded among the findings. Participants were representatives of universities, industrial sectors, civil societies and research organizations. In this respect, $52 \%$ of the participants were representatives of research institutions while industry and academia were represented by 41\%. Previous studies showed that expertise and flow of exchanges are of higher importance than the number of participants (Nguyen, Chen et al. 2019). On the other front, previous empirical evidence showed that lower number of participants than the one used in the present study could have high social acceptance (Rowe and Wright 2011, Proskuryakova 2019). Other studies showed that increasing the number of participants to capture more reflections and opinions could elongate the process with more dragging sessions and accordingly might increase the dropout rate of experts (Okoli and Pawlowski 2004). The diversity of participants and stakeholders involved in the present study is aligned with previous studies, which showed that the heterogenous groups 
INSIGHTS INTO REGIONAL DEVELOPMENT

ISSN 2669-0195 (online) http://jssidoi.org/jesi/

2019 Volume 1 Number 4 (December)

http://doi.org/10.9770/IRD.2019.1.4(6)

potentiate the forecasting power from one side while reducing the polarization effect and enhancing the accuracy of findings from the other side (Yaniv 2011).

\subsection{Important future topics}

The participants were asked to assess importance for each of the 180 identified topics clustered in 14 energy areas. The study shows that the topic is of high importance if reached consensus equal or higher than $70 \%$ by all participants. The results showed that 14 topics in 5 cluster areas (Bioenergy, enabling environments, energy storage, fossil Fuels, urban planning and building) achieved relative consensus for being important at the national level with an agreement of over $70 \%$ (Table 3). While regarding the topics of high importance at both the national and international levels, the results showed that 50 topics in 12 cluster areas (Bioenergy, energy efficiency, energy storage, enabling environments, hydrogen energy, materials for energy, mixed energy technologies, nuclear energy, other renewable energy, solar energy and transportation) achieved relative consensus with agreement over $70 \%$.

To limit the inadvertently polarization effect which might result into an interdependent agreement of experts (spurious consensus), each group had to have a diverse level of expertise and different stakeholders while having iterative Delphi rounds. Within this methodological approach, the adopted consensus process is aligned with other previous studies (Kerr and Tindale 2011, Önkal, Lawrence et al. 2011, Proskuryakova 2019).

Table 3. Topics importance for Egypt with highest degree of consensus among the respondents (70\% consensus or higher)

\begin{tabular}{|c|c|c|}
\hline Area & Topic & $\begin{array}{l}\text { Precentage degree of } \\
\text { consensus of } \\
\text { respondents }\end{array}$ \\
\hline Enabling environments & $\begin{array}{l}\text { A legislation was developed for a fair distribution of natural resources in terms } \\
\text { of use and energy pricing by doing a fair population survey }\end{array}$ & 100 \\
\hline $\begin{array}{l}\text { Urban planning and } \\
\text { Building }\end{array}$ & $\begin{array}{l}\text { A system of recycling garbage is created that is easy \& simple to reuse this } \\
\text { garbage in the production of energy, this does not need labor as each member of } \\
\text { the family can manage it. }\end{array}$ & 89 \\
\hline Enabling environments & $\begin{array}{l}\text { Human behavior and environmental ethics were modified through education - } \\
\text { culture - media }\end{array}$ & 86 \\
\hline Enabling environments & $\begin{array}{l}\text { the general and technical education curriculum technical had included new } \\
\text { topics about the use of green energy and energy management technology }\end{array}$ & 86 \\
\hline Enabling environments & $\begin{array}{l}\text { Issued Laws for the construction of new housing on the installation of solar } \\
\text { water heaters as a condition of the construction license terms }\end{array}$ & 86 \\
\hline Fossil Fuels & $\begin{array}{l}\text { Proper development plans were set for improving and developing refinery } \\
\text { plants in Egypt }\end{array}$ & 82 \\
\hline $\begin{array}{l}\text { Urban planning and } \\
\text { Building }\end{array}$ & $\begin{array}{l}\text { Transparent solar cells (Integrated solar cells) in curtain walls and opening and } \\
\text { skylight }\end{array}$ & 78 \\
\hline Energy storage & $\begin{array}{l}\text { Established the targeted collaboration projects with South Asian countries, } \\
\text { China, Japan \& Korea. }\end{array}$ & 75 \\
\hline Energy storage & Establishment of centers of excellent for improving energy storage media. & 75 \\
\hline Enabling environments & $\begin{array}{l}\text { The education curriculum designers and makers and the general standards } \\
\text { nationalism's vision was changed to increase awareness of the new concepts } \\
\text { associated with energy alternatives and population awareness and recycling of } \\
\text { waste }\end{array}$ & 71 \\
\hline Enabling environments & $\begin{array}{l}\text { The rationalization of waste and consumption was insured through good } \\
\text { management of resources to overcome the gap between the increase in the } \\
\text { population growth rate and the amount of resources }\end{array}$ & 71 \\
\hline Enabling environments & Localization for know-how for the manufacture of solar cells and solar heaters & 71 \\
\hline Bioenergy & $\begin{array}{l}\text { A pilot plant was built for the production of biofuel as a nucleus for circulation } \\
\text { in Egypt }\end{array}$ & 70 \\
\hline
\end{tabular}




\subsection{Time of occurance}

The Delphi topics and their forecasted time of occurrence were assessed by all participants and respondents were asked to assess frequent times of occurrence of all Delphi topics in the duration between 2018 to 2040. The assessment was performed with respect to, first, the time of technical realization which refers to the time when the technology, process or solutions could be ready at the technical level (Table 4). And second, the time of social acceptance which refers to the time when a particular technology, service or solution could impact the market and local communities in Egypt (Table 5). An average time of occurrence of all the captured statements was assessed after the second round of Delphi. The majority of Delphi topics were expected to be technologically realized in the duration between 2018-2022, while the reset of topics (25\%) are expected to be realized after the year 2022. The topics that are expected to be realized after 2027 addressed issues regarding the use of electric and hybrid cars, use of advanced material in hydrogen storage, hybrid unit of wind and solar and hydrogen PV, nuclear reactors components and the treatment of nuclear wastes. Table 3 and 4 list these specific topics regarding the technology realization time and social realization time. For the topics achieved high social realization with either market impact or high local community acceptance in Egypt (Table 3), the majority of topics (75\% of all topics) are expected to be realized during the years 2018-2027, while the reset of topics (25\%) are expected to be realized after the year 2027. The topics that could be realized after year 2027 addressed issues related to specific areas of nuclear energy, bio-energy, energy efficiency, energy storage and hydrogen energy.

Table 4. Allocation of topics according to technological realization time

\begin{tabular}{|c|c|c|c|c|c|c|}
\hline \multirow[b]{2}{*}{ Area } & \multicolumn{5}{|c|}{ Number of topics per Technological Realization Time } & \multirow{2}{*}{$\begin{array}{c}\text { Total Number } \\
\text { of topics }\end{array}$} \\
\hline & $2018-2022$ & $2022-2027$ & $2027-2032$ & $2032-2037$ & $\begin{array}{l}\text { Already } \\
\text { realized }\end{array}$ & \\
\hline Bioenergy & 13 & 0 & 0 & 1 & 1 & 15 \\
\hline Energy efficiency & 7 & 2 & 1 & 0 & 3 & 13 \\
\hline Enabling environments & 9 & 6 & 1 & 0 & 0 & 16 \\
\hline Energy storage & 11 & 4 & 1 & 0 & 0 & 16 \\
\hline Environment Impact & 12 & 2 & 0 & 0 & 0 & 14 \\
\hline Fossil Fuels & 5 & 3 & 0 & 0 & 1 & 9 \\
\hline Hydrogen energy & 14 & 0 & 1 & 0 & 0 & 15 \\
\hline Materials for energy & 8 & 2 & 0 & 0 & 0 & 10 \\
\hline Mixed energy technologies & 14 & 1 & 0 & 1 & 0 & 16 \\
\hline Nuclear Energy & 3 & 3 & 1 & 3 & 0 & 10 \\
\hline Other Renewable energy & 6 & 0 & 0 & 0 & 1 & 7 \\
\hline Solar Energy & 13 & 1 & 0 & 0 & 0 & 14 \\
\hline Transportation & 4 & 1 & 0 & 0 & 3 & 8 \\
\hline $\begin{array}{l}\text { Urban planning and } \\
\text { Building }\end{array}$ & 16 & 0 & 0 & 0 & 1 & 17 \\
\hline Total & 135 & 25 & 5 & 5 & 10 & 180 \\
\hline
\end{tabular}


INSIGHTS INTO REGIONAL DEVELOPMENT

ISSN 2669-0195 (online) http://jssidoi.org/jesi/ 2019 Volume 1 Number 4 (December) http://doi.org/10.9770/IRD.2019.1.4(6)

Table 5. Allocation of topics according to Social realization time

\begin{tabular}{|c|c|c|c|c|c|c|c|}
\hline \multirow[b]{2}{*}{ Area } & \multicolumn{6}{|c|}{ Number of topics per Social Realization Time } & \multirow{2}{*}{$\begin{array}{c}\text { Total } \\
\text { Number of } \\
\text { topics }\end{array}$} \\
\hline & $2018-2022$ & $2022-2027$ & $2027-2032$ & $2032-2037$ & $\begin{array}{l}2037- \\
2042\end{array}$ & $\begin{array}{l}\text { Already } \\
\text { realized }\end{array}$ & \\
\hline Bioenergy & 7 & 5 & 2 & 0 & 1 & 0 & 15 \\
\hline Energy efficiency & 0 & 7 & 3 & 0 & 2 & 1 & 13 \\
\hline Enabling environments & 6 & 4 & 6 & 0 & 0 & 0 & 16 \\
\hline Energy storage & 6 & 6 & 3 & 0 & 1 & 0 & 16 \\
\hline Environment Impact & 8 & 6 & 0 & 0 & 0 & 0 & 14 \\
\hline Fossil Fuels & 4 & 5 & 0 & 0 & 0 & 0 & 9 \\
\hline Hydrogen energy & 9 & 0 & 5 & 1 & 0 & 0 & 15 \\
\hline Materials for energy & 3 & 4 & 3 & 0 & 0 & 0 & 10 \\
\hline $\begin{array}{c}\text { Mixed energy } \\
\text { technologies }\end{array}$ & 7 & 8 & 1 & 0 & 0 & 0 & 16 \\
\hline Nuclear Energy & 0 & 0 & 10 & 0 & 0 & 0 & 10 \\
\hline Other Renewable energy & 2 & 2 & 3 & 0 & 0 & 0 & 7 \\
\hline Solar Energy & 6 & 5 & 3 & 0 & 0 & 0 & 14 \\
\hline Transportation & 3 & 4 & 1 & 0 & 0 & 0 & 8 \\
\hline $\begin{array}{l}\text { Urban planning and } \\
\text { Building }\end{array}$ & 16 & 1 & 0 & 0 & 0 & 0 & 17 \\
\hline Total & 77 & 57 & 40 & 1 & 4 & 1 & 180 \\
\hline
\end{tabular}

\subsection{The actions that the government should address in the near future}

The respondents were asked to select the actions needed to realize the topics in the future with respect to strategy formulation, human resources, capacity building, legal system reform, academia and public research institution reform, industry support, public acceptance and the required investment. The results showed four actions with the highest consensus among the respondences which represent the actions of high priority at both the technological and social levels. The intervention for strategy formulation has achieved a consensus of $49 \%$ of all participants and it is followed by investment requirements (47\%), reform of higher Education establishments and public research institution (41\%) and Industry support action (40\%). Figure 2 shows the actions that the government shall address in all 14 energy areas.
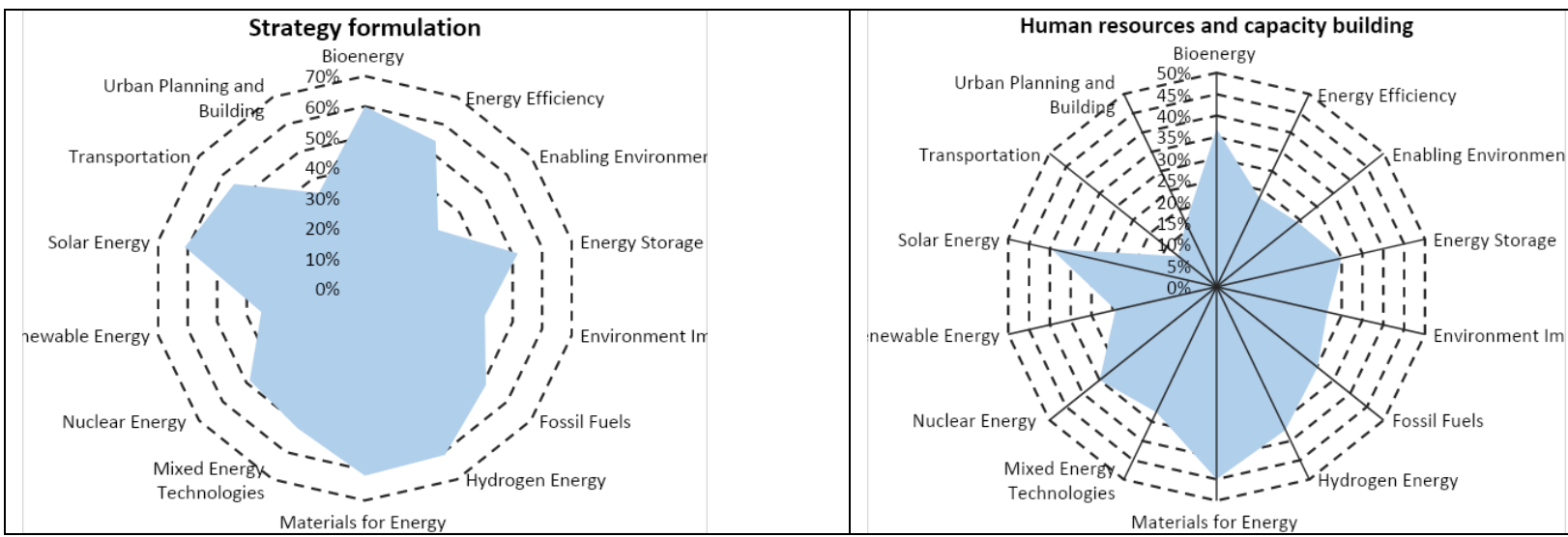
INSIGHTS INTO REGIONAL DEVELOPMENT

ISSN 2669-0195 (online) http://jssidoi.org/jesi/ 2019 Volume 1 Number 4 (December) http://doi.org/10.9770/IRD.2019.1.4(6)

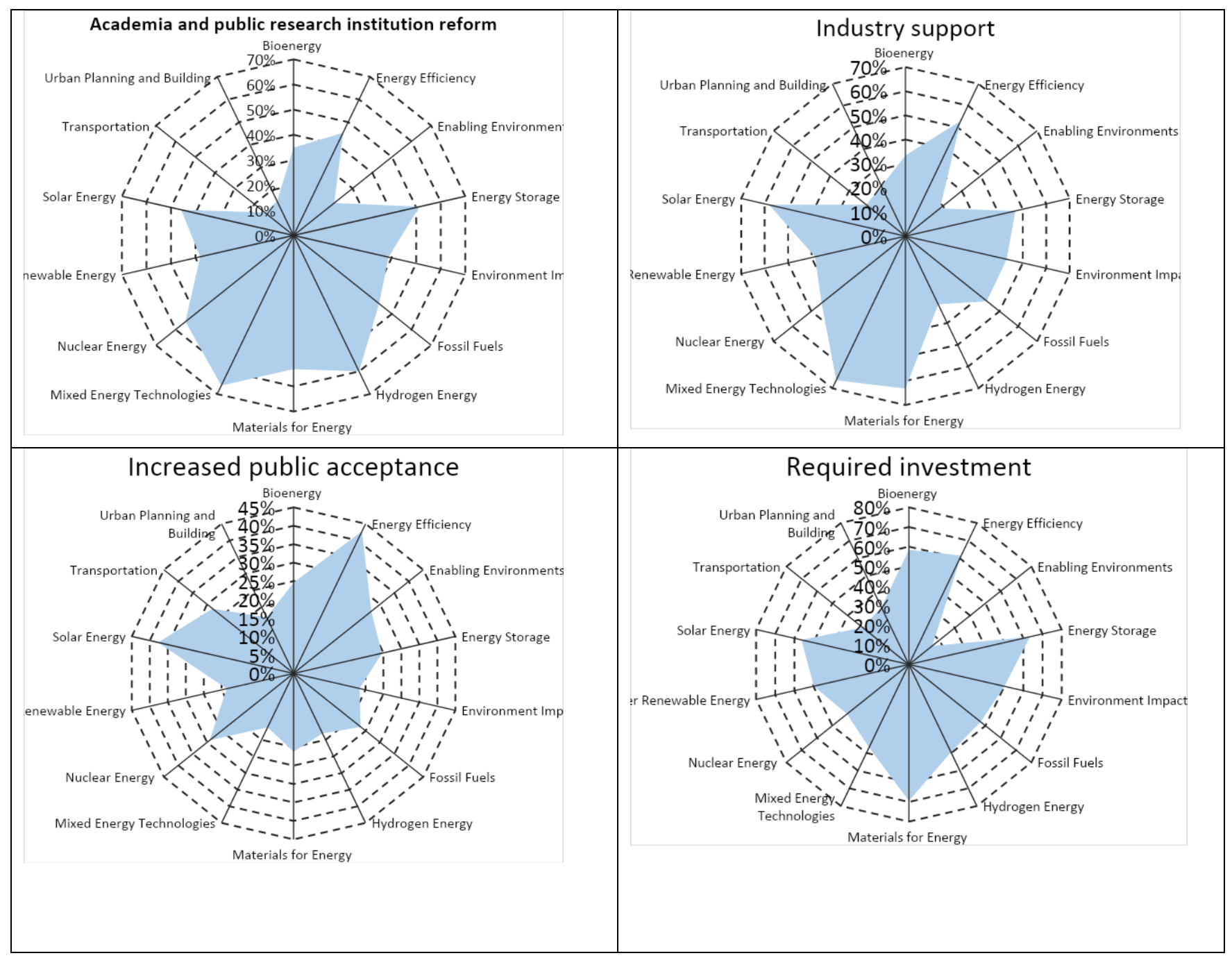

Figure 2. Specific actions require government interventions

\subsection{Sectors that will make the identified Delphi topics realized in future}

The respondents were asked to select the sectors that will make technological and social realization possible for each of the Delphi topics and across all the 14 cluster areas with respect to stakeholder type including higher education establishment, public research organization, private enterprise, a collaboration of multiple sectors or through the support of international organizations. Results indicate that the first priority (highest consensus percentage) shall focus on the need for collaboration among multiple sectors for topics to be realised at technological and social level and more specifically for the subtopics of the areas of bio-energy, energy efficiency, energy storage, environment impact, enabling environments, materials for energy, renewable energy, solar energy, transportation and urban planning and building (Figure 3). 


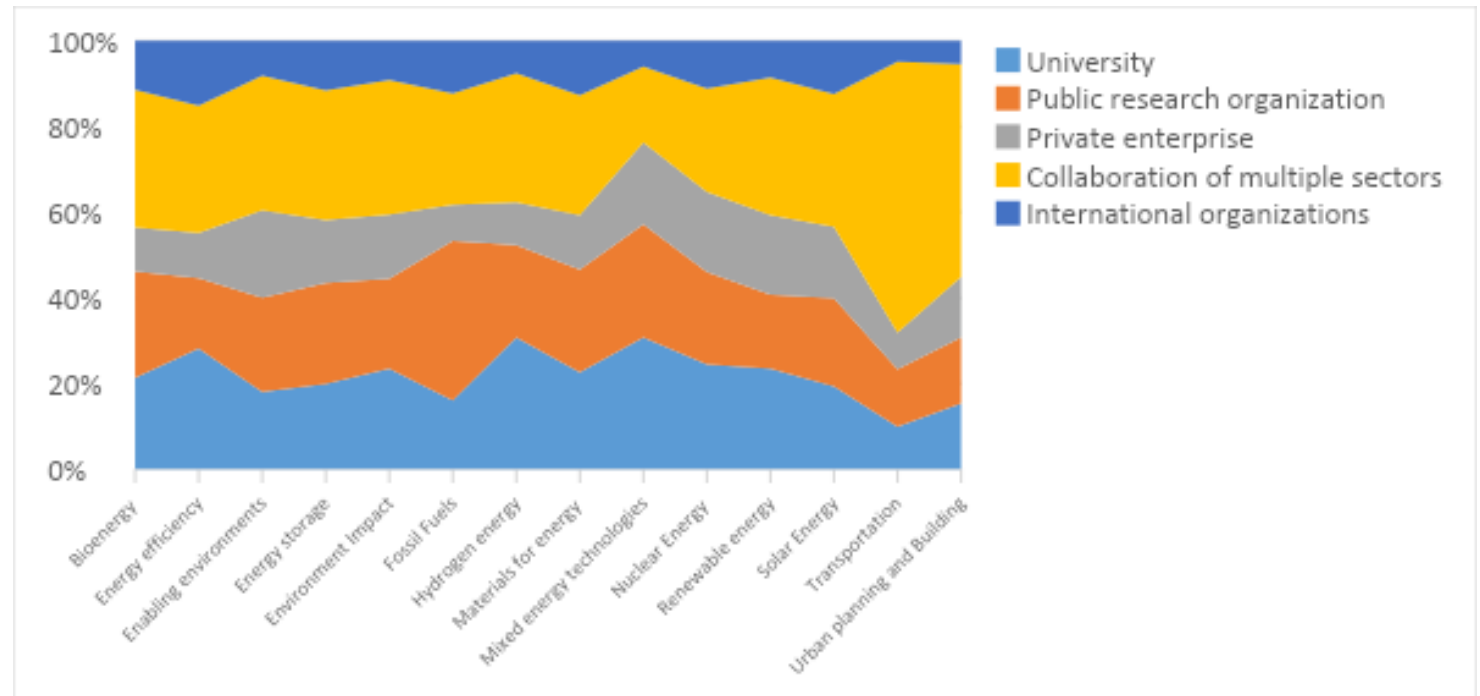

Figure 3. Sectors that will make Delphi topics realized in future

On the other front, participants expected higher education establishments to address that the topics of fossil fuels areas to be impactful while the contribution of public research organization could significantly topics of nuclear energy and mixed energy technologies areas.

\section{Conclusions}

In this work large data set of topics were screened based on a literature review, existing policy briefs, strategies and relevant components of Egypt vision 2030. Topics were then grouped per cluster area and sub-structured to a matrix of technical questions to develop specific questionnaire relevant to each target group. Real time survey was performed through an iterative process. About 50\% of Egypt's energy demand was foresighted to be met by renewable energies around 2030. The results showed that all types of energies would not only provide economic and environmental benefits but also improve living standards. This work demonstrates that involving large diversity of expertise and different stakeholders, comprising heterogenous groups, would potentiate the forecasting power, reduce the polarization effect, and enhance the reliability of the foresight exercise. The amalgamation of social, economic and political aspects in technology-based foresight ensures relevance of the findings to a wide range of beneficiary.

This work utilised findings of "Egypt leaps" project that is funded by the Academy of Scientific Research in Egypt.

\section{References}

Aengenheyster, S., K. Cuhls, L. Gerhold, M. Heiskanen-Schüttler, J. Huck and M. Muszynska (2017). Real-Time Delphi in practice - A comparative analysis of existing software-based tools. Technological Forecasting and Social Change 118: 15-27. https://doi.org/10.1016/j.techfore.2017.01.023

Armin Razmjoo, A., Sumper, A. and Davarpanah, A. (2019). Development of sustainable energy indexes by the utilization of new indicators: A comparative study. Energy Reports 5: 375-383. https://doi.org/10.1016/j.egyr.2019.03.006

Breisinger, C., Mukashov, A., Raouf, M. and Wiebelt, M. (2019). Energy subsidy reform for growth and equity in Egypt: The approach matters. Energy Policy 129: 661-671. https://doi.org/10.1016/j.enpol.2019.02.059 


\section{INSIGHTS INTO REGIONAL DEVELOPMENT}

ISSN 2669-0195 (online) http://jssidoi.org/jesi/

2019 Volume 1 Number 4 (December)

http://doi.org/10.9770/IRD.2019.1.4(6)

Di Zio, S., Castillo Rosas, J.D., and Lamelza, L. (2017). Real Time Spatial Delphi: Fast convergence of experts' opinions on the territory. Technological Forecasting and Social Change 115: 143-154. https://doi.org/10.1016/j.techfore.2016.09.029

Ghinolfi, D., El Baz, H. G., Borgonovi, E., Radwan, A., Laurence, O., Sayed, H. A., De Simone, P. , Abdelwadoud, M., Stefani, A., Botros, S. S., and Filipponi, F. (2014). A model for southern mediterranean research institute self-assessment: A SWOT analysis-based approach to promote capacity building at Theodor Bilharz Research Institute in Cairo (Egypt). Arab Journal of Gastroenterology 15(3-4): 92-97. http://dx.doi.org/10.1016/j.ajg.2014.05.003

Gupta, U. G. and Clarke, R. E. (1996). Theory and applications of the Delphi technique: A bibliography (1975-1994). Technological Forecasting and Social Change 53(2): 185-211. https://doi.org/10.1016/S0040-1625(96)00094-7

Ibrahim, A. (2012). Renewable energy sources in the Egyptian electricity market: A review. Renewable and Sustainable Energy Reviews 16(1): 216-230. https://doi.org/10.1016/j.rser.2011.07.149

Kerr, N. L. and Tindale, R. S. (2011). Group-based forecasting?: A social psychological analysis. International Journal of Forecasting 27(1): 14-40. https://doi.org/10.1016/j.ijforecast.2010.02.001

Kononiuk, A. and Magruk, A. (2015). Wild Cards in Polish Foresight Practice. Procedia - Social and Behavioral Sciences 213: 951-956.

Lee, J. and Yang, J.-S. (2018). Government R\&D investment decision-making in the energy sector: LCOE foresight model reveals what regression analysis cannot. Energy Strategy Reviews 21: 1-15. https://doi.org/10.1016/j.sbspro.2015.11.510

Markley, O. (2011). A new methodology for anticipating STEEP surprises. Technological Forecasting and Social Change 78(6): 10791097. https://doi.org/10.1016/j.techfore.2011.01.008

Nguyen, S., P. Chen, S.-L., Du, Y and Shi, W. (2019). A quantitative risk analysis model with integrated deliberative Delphi platform for container shipping operational risks. Transportation Research Part E: Logistics and Transportation Review 129: 203-227. https://doi.org/10.1016/j.tre.2019.08.002

Okoli, C. and Pawlowski, S. D. (2004). The Delphi method as a research tool: an example, design considerations and applications. Information \& Management 42(1): 15-29. https://doi.org/10.1016/j.im.2003.11.002

Proskuryakova, L. (2019). Foresight for the ‘energy' priority of the Russian Science and Technology Strategy. Energy Strategy Reviews 26: 100378. https://doi.org/10.1016/j.esr.2019.100378

Radwan, A. (2018). Science and innovation policies in North African Countries: Exploring challenges and opportunities. Entrepreneurship and Sustainability Issues 6(1): 268-282. https://doi.org/10.9770/jesi.2018.6.1(17)

Radwan, A. and Sakr, M. (2017). Review of the Egypt science and technology system; SWOT analysis. Entrepreneurship and Sustainability Issues 5(2): 204-211. https://doi.org/10.9770/jesi.2017.5.2(3)

Renzi, A. B. and Freitas, S (2015). The Delphi Method for Future Scenarios Construction. Procedia Manufacturing 3: 5785-5791. https://doi.org/10.1016/j.promfg.2015.07.826

Rezk, M. A., Ibrahim, H. H., Radwan, A., Sakr, M. M., Tvaronavičienė, M.; Piccinetti, L. (2016). Innovation magnitude of manufacturing industry in Egypt with particular focus on SMEs. Entrepreneurship and Sustainability Issues 3(4): 307318. https://doi.org/10.9770/jesi.2016.3.4(1)

Rowe, G. and Wright, G (2011). The Delphi technique: Past, present, and future prospects - Introduction to the special issue. Technological Forecasting and Social Change 78(9): 1487-1490. https://doi.org/10.1016/j.techfore.2011.09.002

Shouman, E. R. (2017). International and national renewable energy for electricity with optimal cost effective for electricity in Egypt. Renewable and Sustainable Energy Reviews 77: 916-923. https://doi.org/10.1016/j.rser.2016.12.107

Suding, P. H. (2011). Struggling between resources-based and sustainable development schemes-An analysis of Egypt's recent energy policy. Energy Policy 39(8): 4431-4444. https://doi.org/10.1016/j.enpol.2010.11.010

Yaniv, I. (2011). Group diversity and decision quality: Amplification and attenuation of the framing effect. International Journal of Forecasting 27(1): 41-49. https://doi.org/10.1016/j.ijforecast.2010.05.009 
INSIGHTS INTO REGIONAL DEVELOPMENT

ISSN 2669-0195 (online) http://jssidoi.org/jesi/ 2019 Volume 1 Number 4 (December) http://doi.org/10.9770/IRD.2019.1.4(6)

Önkal, D., Lawrence, M. and Zeynep Sayım, K. (2011). "Influence of differentiated roles on group forecasting accuracy." International Journal of Forecasting 27(1): 50-68. https://doi.org/10.1016/j.ijforecast.2010.03.001

\section{Aknowledgements}

This research wasmsupported by the project, which has received funding from the European Union's Horizon 2020 research and innovation programme European Research Council (ERC) under the European Union's Horizon 2020 research and innovation programme Marie Sklodowska-Curie Research and Innovation Staff Exchanges ES H2020-MSCA-RISE-2014 CLUSDEVMED (2015-2019) Grant Agreement Number 645730730

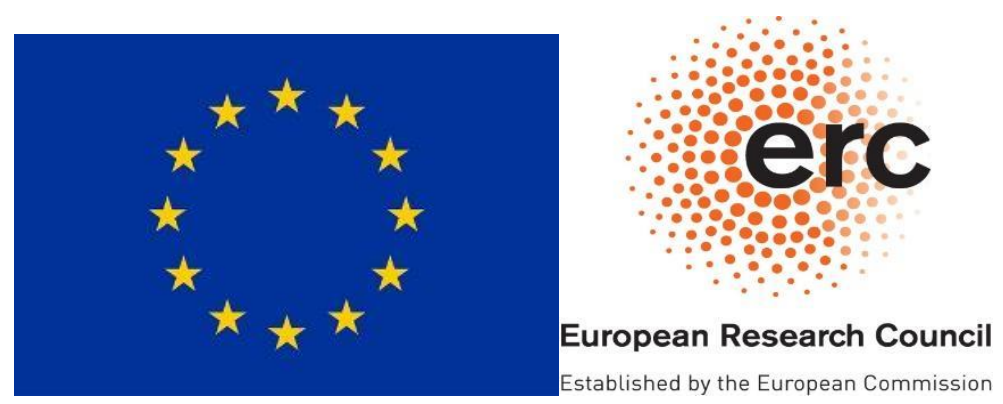

Mohamed Ramadan A. REZK, holds PhD in nanotechnology. He has expertise in the evaluation of science, technology and innovation systems. He is currently the Director of Egyptian Science, Technology and Innovation Observatory at the Egyptian Academy of Scientific research and technology. In the present study, Mohamed conceived and designed the study and supported the data analysis.

ORCID ID:https://orcid.org/0000-0002-7677-3072

Amr RADWAN is the Head of Research and Innovation Management Department at the Egyptian Academy of Scientific Research \& Technology (ASRT). Amr is an experienced researcher in the fields of innovation systems, research governance, science policy and technology development, and co-authored several regional strategies and roadmaps for science, technology development and Innovation. He has a pharmacology background with professional industry experience and has also obtained Masters of Business Administration (MBA) and a several diplomas in Intellectual Property Rights and Innovation Management. In the present study, Amr prepared the manuscript, preformed analytical review and supported the analysis of the study.

ORCID ID: https://orcid.org/0000-0002-5567-6708 
INSIGHTS INTO REGIONAL DEVELOPMENT

ISSN 2669-0195 (online) http://jssidoi.org/jesi/

2019 Volume 1 Number 4 (December)

http://doi.org/10.9770/IRD.2019.1.4(6)

Nahed M. SALEM, has biotechnology background and is currently a researcher at the Egyptian Science, Technology and Innovation Observatory, the Egyptian Academy of Scientific research and technology. In the present study, Nahed analyzed data and supported the overall design of the study.

ORCID ID: https://orcid.org/0000-0003-3536-8502

Mahmoud SAKR has been the Head of Genetic Engineering \& Biotechnology Division at the national research center in Egypt before he has been appointed as the executive director of Science, Technology and Development Fund in Egypt. He is currently the President of the Academy of Scientific Research and Technology/Ministry of scientific research in Egypt. He has been awarded many national awards including the State Prize for scientific encouragement in advanced biotechnology. $\mathrm{He}$ is a member of several strategic committees at national and international bodies, steering boards of a number of Egyptian research institutions and has managed national and multinational competie projects. In the present study, Mahmoud supported the manuscript writing, analysis of data and overall design.

ORCID ID: https://orcid.org/0000-0001-9467-9250

Manuela TVARONAVIČIENĖ

ORCID ID: http://orcid.org/0000-0002-9667-3730

Register for an ORCID ID:

https://orcid.org/register

Copyright (C) 2019 by author(s) and VsI Entrepreneurship and Sustainability Center

This work is licensed under the Creative Commons Attribution International License (CC BY).

http://creativecommons.org/licenses/by/4.0/

(c) (i) Open Access 